UNIVERSITY

OF DEBRECEN

FACULTY OF

HEALTH

NYÍREGYHÁZA

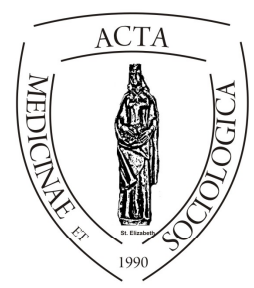

ACTA

MedSoC

VOLUME 7.

2016

\title{
Sztómás betegek életminőség-vizsgálata Szlovákiában
}

\author{
Stela Gilanová \\ Szent Erzsébet Egészségügyi és Szociális Munka Föiskola
}

\begin{abstract}
Slovakian life quality study of patients with stoma. A person with a stoma is geting in to a dificult life situation, which is not easily manageable. Due to the serious health situation, their life and life quality is changing. The main aim is to identify factors, which in varying degrees affect the quality of life of an ostomate. The actual empirical research with the objectives, areas of concern and research questions are presented in the chapter first. The author presents slovak research results in the second main part of the paper.
\end{abstract}

Keywords: Quality of life, Ostomy, Ostomate, Personal well-being

Absztrakt. A kivezetett sztómával élő emberek nehéz élethelyzetbe kerülnek, melyet nem könnyü kezelni. Betegségük miatt változik az életformájuk és életminőségük. A bemutatott kutatás fó célja azonosítani azon faktorokat, melyek befolyásolják a sztómás beteg életminőségét. Az első fejezet a kutatási célok és kérdések rögzítése után a minta kiválasztásának módszereivel és módszertanával, valamint az egyes kutatási módszerek időtervével foglalkozik. A szerző a második fö részben bemutatja a sztómás állapot életminőséggel kapcsolatos vizsgálati eredményeit.

Kulcsszavak: életminőség, sztóma, sztómás beteg, személyes jólét

DOI: $10.19055 / \mathrm{ams} .2016 .7 / 22-23 / 1$ 


\section{Bevezetés}

Az életminőséggel kapcsolatban a legalapvetőbb fogalmi kiindulópont az élet értéke: „melyet nemzetközileg az életre való joggal, mint az emberi jogok alappillérével védenek. Az élet értékét önmaga adja és az életminőség ennek az értéknek a beteljesedését jelenti a minimális emberi optimumon, miközben függ ennek a társadalmi feltételeitől is. Más az értéksíkja az életminőségnek, mely összefügg az egyén és a csoport differenciált értékorientációjával" (Halečka 2001: 48.).

Az életminőség fogalmát, mint koncepciót, széles körben használják a különböző segítő foglalkozásokban, így az ápolástanban is. Az életminőség egy komplex fogalom, melynek több dimenziója van. A dimenziók kialakításánál egyrészt az objektív mutatókat kell figyelembe venni (pl. a testi és lelki egészség orvosi mutatói, munkahely és bevétel, lakáskérdés, szabadidős tevékenységek, más személy segítségétől függés, azon személyek száma, akikkel a személy kapcsolatban van), másrészt a szubjektív mutatókat is vizsgálni kell (pl. elégedettség a munkahelyen, a családi életben, a baráti kapcsolatok minőségével, otthonérzés, biztonságérzés) (Matoušek, 2007).

Surynek és Nový (2006) szerint az életminőség az életforma aspektusait képviseli, mely többek között az élet változatosságával van összefüggésben. Más életminőség vizsgálatok szerint az életminőség fogalma csak érintőlegesen, közvetve van összefüggésben az anyagi szükségletek kielégítésével. A főbb meghatározó életminőség-dimenziók inkább olyan szükségletek kielégítésével állnak kapcsolatban, melyeknél az anyagi biztonság kevésbé jelentős, vagy egyáltalán nincs is jelen (In Heřmanová 2012).

Šalgovičová (2007) szerint az életminőség egy dinamikus, változó fogalom, amelyet a körülmények egymásra hatása alakít, sok eleme az emberi és a társadalmi fejlődéssel kapcsolatos; ezek lényegében a szociális, az egészségi, a környezetvédelmi és a gazdasági körülmények leképeződésén keresztül mutatkoznak. Ezen objektív dimenziókon kívül az élet szubjektív megélését is vizsgálnia kell a kutatónak, ami például az egészség, a biztonság, a társadalmi elismerés és befogadás, teljesítőképesség, az érzelmi telítettség állapotában és formájában jelenik meg (In Heřmanová, 2012).

A testi fogyatékkal élők életminősége sok esetben a fokozottabb rászorultság okán a családon belüli életelégedettségétól nagyobb mértékben függ. A család stabilitása, melyben a testi fogyatékkal élő családtag él - annak minden rendszerének és alrendszerének müködése - komoly tesztje a partnerek személyiségérettségének (Matoušek, Koláčková, Kodymová, 2005).

Kováč (2007) szerint a betegségekkel küzdők életminőség-viszonyai nem csak az érintettek problémája, hanem az egészséges populáció ügye is. 
A sztómások életminőségének kutatása - Problémás területek a gyakorlatban

A sztómával élő személy betegsége és a kezelések okán nehéz élethelyzetbe kerül, amit nem lehet könnyen kezelni. Néhány súlyosabb esetben a kialakult helyzet személyes feldolgozásához, a hétköznapokba való visszatéréshez több segítő szakember közremüködése is szükséges.

A meghatározás szerint a sztómás beteg olyan súlyos testi fogyatékkal élő személy, akinek átmenetileg vagy örökre kivezették valamilyen szervét a hasfalra, leggyakrabban a vastagbelet (kolosztómia), vékonybelet (ileosztómia) vagy a húgyvezetéket (urosztómia). Ezzel a beavatkozással alapvető változás áll be az élettani funkcióknál - ellenőrizhetetlen székletürítés, béltartalom vagy vizeletürítés, valamint elkerülhetetlen a sztómás segédeszközök használata, aminek eredménye a jelentősen megváltozott, megromlott életminőség (http://www.slovilco.sk/definicia/).

Az egészségromlás súlyossága miatt változik a beteg életvitele, életminősége. A sztómás betegeknek olyan problémái lehetnek, melyek megnehezítik az életüket vagy megakadályozzák a teljes és minőségi élet élésében. Az egyik fő probléma a sztómás beteg pszichés alkalmazkodása az adott helyzethez.

\section{A kutatás célja}

A dolgozatban bemutatott kutatás fó célja azon tények azonosítása, melyek különböző mértékben befolyásolják a sztómás beteg életminőségét.

Részleges célok:

Megállapítani, hogy hogyan hat a sztómás időszak a sztómás beteg életminőségére.

Megállapítani, hogy milyen különbség figyelhető meg a kivezetés előtti és a kivezetés utáni életminőségben.

\section{Kutatási kérdések}

A sztóma kivezetés óta eltelt idő hogyan befolyásolja az életminőség megítélését? Milyen mértékben volt hatással az adott személy a sztóma kivezetése előtti élete a kivezetés utáni életminőségre?

\section{Hipotézisek}

1 hipotézis: Azok a sztómások, akiknek régebben van sztómájuk, magasabb szubjektív elégedettségről számoltak be életminőségükkel kapcsolatban a kivezetés után, mint azok a betegek, akiknek rövidebb ideje van kivezetésük.

2 hipotézis: A válaszadók, akik szubjektív elégedettséget tüntettek fel az életminőségük terén a sztóma előtti életükből, ugyanolyan szubjektív elégedettséget tüntetnek fel az életminőségükről a kivezetés elvégzése után. 


\section{A kutatás módszerei és módszertana}

A vizsgálat során kérdőíves adatfelvétel segítségével történt az adatgyüjtés. Az anonim kérdőív nagyrészt személyes megkeresés útján jutott el szlovák sztómás betegekhez. Egyes betegeket Ilco klubokban tartott találkozók során sikerült elérni. A kérdőívek egy része szakrendelőkbe került, ahol az ott dolgozó egészségügyi nővér segített az adatfelvételben. Néhány beteg a kérdőívet otthon töltötte ki. 128 kérdőív került az Ilco klubokba; itt a válaszadási arány teljes, 100\% volt. A szakrendelőkbe és az otthoni kitöltésre 72 kérdőív került; a visszaadott kérdőívek száma itt 50 darab volt - 69,44\%-os válaszadási arány. Összességében 200 darab kérdőív került szétosztásra; ebböl 178 kitöltött kérdőív került rögzítésre $-89 \%$-os válaszadási arány.

A kérdőívek előkészítése és az adatfelvétel 2015 júniusa és decembere között zajlott.

\section{Eredmények}

A feldolgozott kérdőívek alapadatai szerint a 178 válaszadó közül 68 nő és 110 férfi volt. A feldolgozás során első lépésben az alapstatisztikák kerülnek bemutatásra, majd erre alapozottan a hipotézisek vizsgálatára kerül sor.

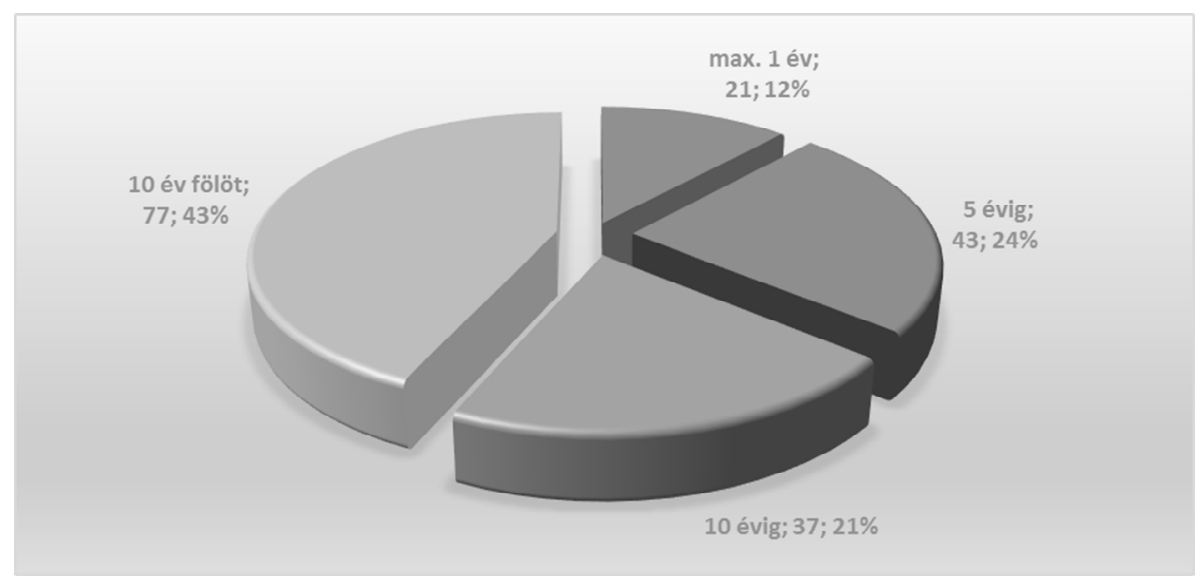

1.ábra. A kutatási minta időtartam szerinti felosztása, milyen hosszú ideje van a betegnek kivezetése (fö, \%). a./ a kivezetés létrehozásának ideje 1 éven belül; b./ a kivezetés létrehozásának ideje 5 éven belül; c./ a kivezetés létrehozásának ideje 10 éven belül; d./ a kivezetés létrehozásának ideje 10 év után. 
A, A sztóma kialakításának ideje. A megkérdezett sztómás betegek a sztóma kialakításának ideje alapján négy csoportba kerültek. Az adatokat az 1. ábra tartalmazza. A megkérdezettek legnagyobb csoportját, 43\%, azok az emberek alkották, akik több, mint 10 éve élnek sztómával, összesen 77 páciens. A legkisebb csoportot a sztómások közül 12\% alkotta, ami 21 megkérdezett volt.

B, Életminőség a sztóma kialakítása után. A sztóma a gyakorlatban a legtöbb esetben az emberi élet megmentését jelenti. Ugyanakkor az ember életében az elégedettséghez nagyon fontos az életminőség szintje. Elengedhetetlen, hogy alkalmazkodjanak a megváltozott élethelyzethez és visszatérjenek a hétköznapi élethez. Azt, hogy ezt a helyzetet hogyan élik meg a sztómás betegek, a kutatásunkból szerzett eredmények alapján a 2. ábra foglalja össze. A sztómásokat arról kérdeztük, hogy hogyan értékelik az életminőségüket a kivezetés után. A sztómások 47\%-a azt tüntette fel, hogy alkalmazkodtak a megváltozott helyzethez és megszokták az életet a kivezetéssel. A válaszadók 34\%-ának fontos, hogy a sztóma megmentette az életüket. A kialakult helyzetet, hogy sztómás, 12\% szükséges rosszként fogja fel. A válaszadó sztómások 6\%-a nagyon elégedett az életminőségével. A válaszadók 1\%-a elégedetlen a helyzetével és korlátozónak tartja. Szintén egy százalék úgy gondolja, hogy ennél rosszabb már nem is történhetett volna vele.

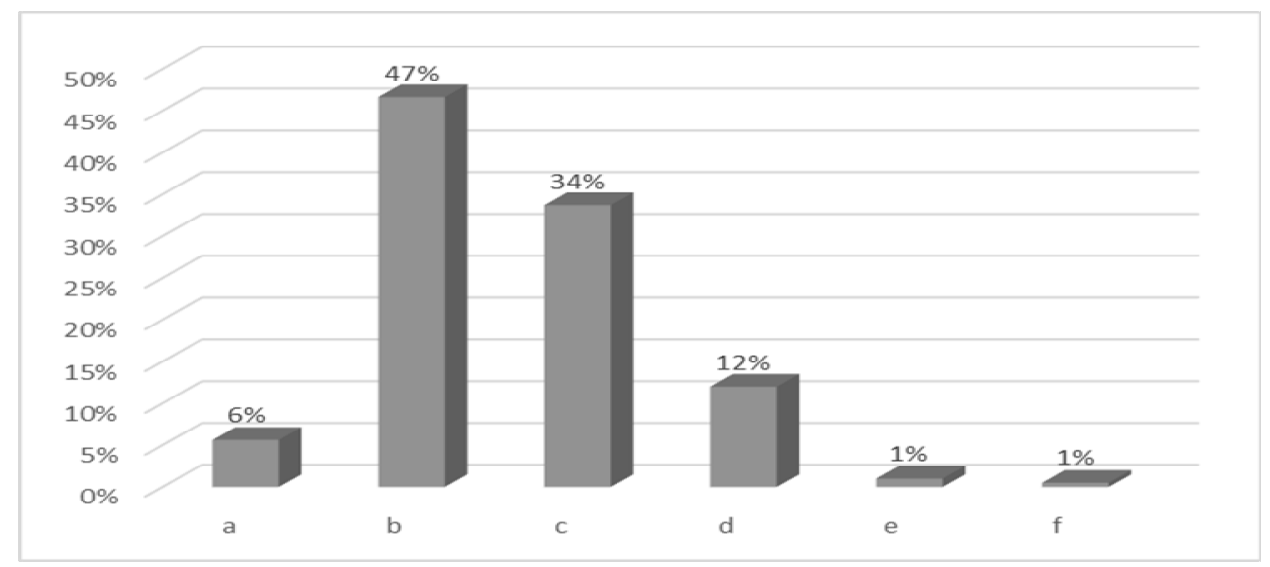

2. ábra. Hogyan értékelné életminőségét a sztóma kialakítása után? a./ nagyon elégedett vagyok; b./ már megszoktam; c./ fontosabb számomra, hogy megmentette az életemet; d./ a kialakult helyzetet, mint szükséges rosszat fogom fel; e./ elégedetlen vagyok, nagyon gátol; f./ ennél már nincs semmi rosszabb. 
C, Életminőség a sztómás kivezetés óta. A sztóma kialakításával gyakran a páciens életét mentik meg, egyúttal javul az életminősége az operáció előtti nehézségeivel szemben. Minket a sztóma kialakítása utáni életminőségükről alkotott véleményük érdekelt. A számskálán 0-tól 6-ig tüntettük fel a számokat, ahol a 0 a nagyon rosszat és a 6 a nagyon jót jelenti. A sztómás betegtől azt kértük, hogy azt a számot karikázza, mely a leginkább tükrözi jelenlegi elégedettségét az életminőségével. A számskálán a 3-ast a sztómások 48,9\% jelölte be. Ebből adódik, hogy a sztómások szinte fele elégedett a kivezetés utáni életminőségével. A válaszadók csak kis aránya $-1,7 \%$ - vallott nagyon rossz életminőségről. Érdekes volt megállapítani, hogy a sztómások szinte 90\%-a a számskálán 3-tól 6-ig jelölt, ami jó, sőt nagyon jó életminőséget jelent. Talán csak a 10\%-uk jelezte, hogy az életminősége a sztóma óta kevésbé jó vagy egészen rossz. (3. ábra)

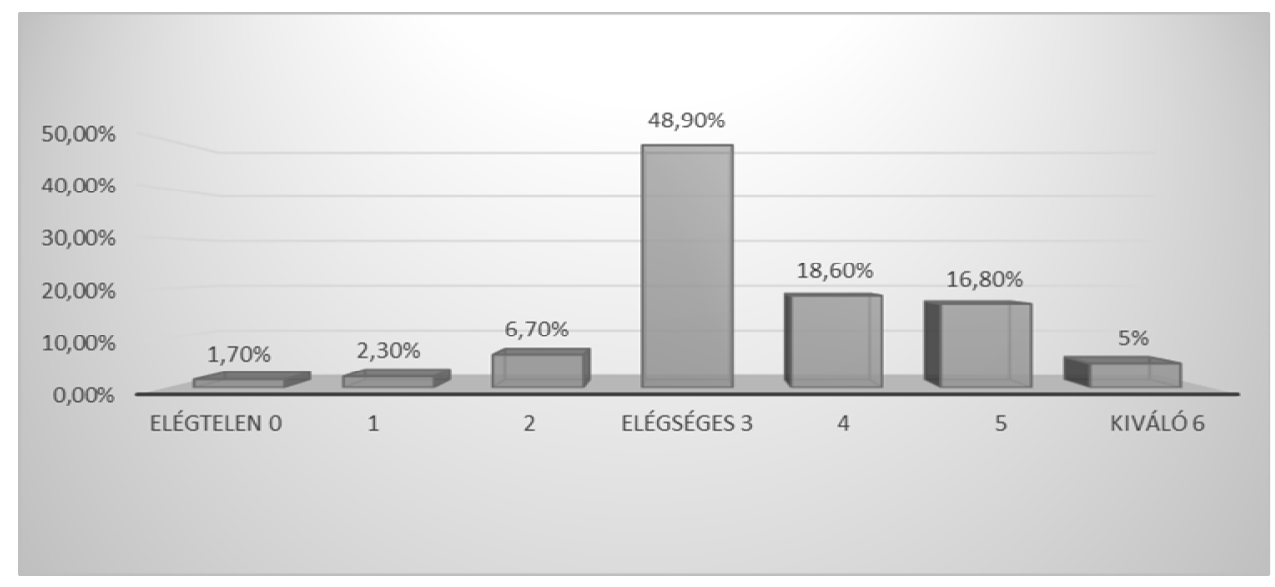

3. ábra. „Hogyan értékelné elégedettségét az életminőségével a kivezetés óta a következő skálán? Kérem, azt a számot karikázza be, amely a legjobban kifejezi elégedettségét. A 0 a nagyon rosszat jelenti, a 6 pedig a nagyon jót."

D, Életminőség a sztómás kivezetés előtt. Az előző kérdéshez hasonlóan ebben a kérdésben is az életminőségre voltuk kíváncsiak, ám a sztóma előttire. A válaszadók újra számskálán értékelték életminőségüket, 0-tól 6-ig, amikor a 0 nagyon rosszat és a 6 nagyon jót jelentett. A kivezetés elvégzése előtti életminőségét a sztómások $14 \%$ kevésbé jónak vagy egészen rossznak tüntette fel. A sztómások több mint 85\%-a a sztóma előtti életminőségét a számskálán 3-tól 6ig jelölte, tehát jónak vagy nagyon jónak értékelte. (4. ábra) 


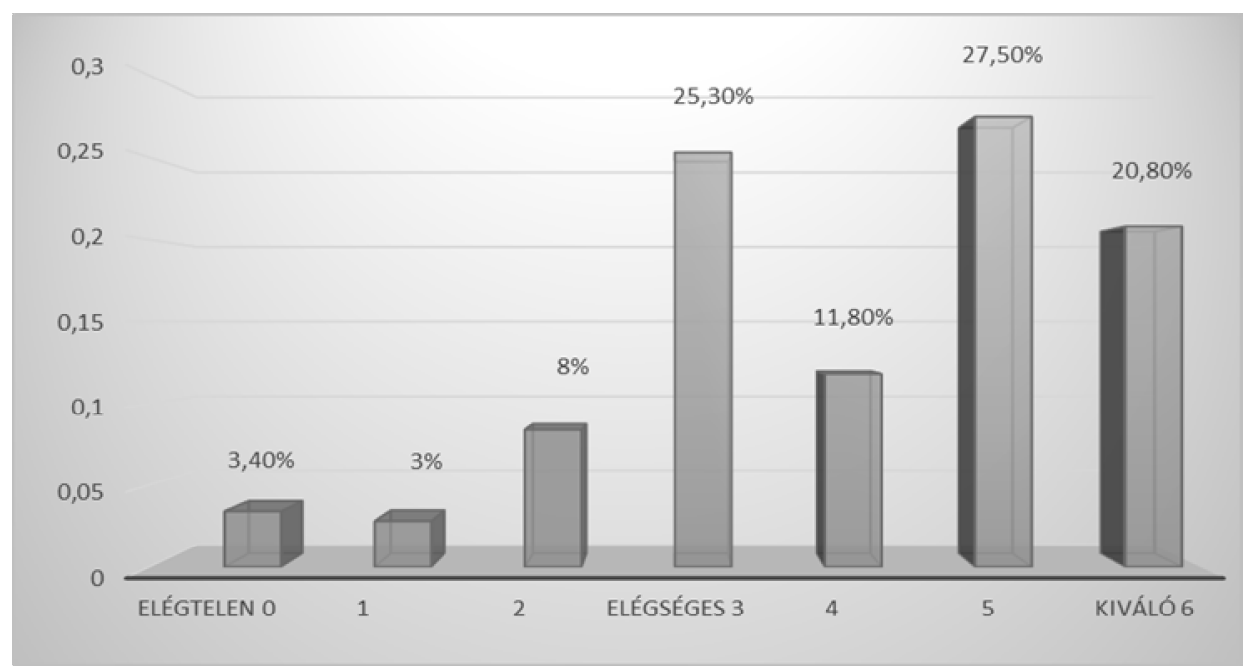

4. ábra. „Hogyan értékelné elégedettségét az életminőségével a kivezetés előt a következő skálán? Kérem, azt a számot karikázza be, amely a legjobban kifejezi elégedettségét.

A 0 a nagyon rosszat jelenti, a 6 pedig a nagyon jót."

\section{1. kutatói kérdés: A sztóma kivezetés óta eltelt idő hogyan befolyásolja az életminőség megítélését?}

Sejtésünk szerint azok a sztómások, akiknek régebben van sztómájuk, magasabb szubjektív elégedettségről vallottak életminőségükkel kapcsolatban a kivezetés után, mint azok a betegek, akiknek rövidebb ideje van kivezetésük.

A hipotézis igazolásához a kutatásban résztvevő sztómások függőségét a sztóma kialakításának hosszától (1. ábra) és a „Hogyan értékelné életminőségét a sztóma kialakítása után?" (2. ábra) kérdéseket vizsgáltuk meg. Feltételeztük, hogy azok a sztómások, akiknek hosszabb ideje van kivezetése az életminőségükről magasabb szubjektív elégedettségről vallanak majd, mint azok, akiknek rövidebb ideje van sztómájuk. Az elemzés során tekintettel kell lennünk arra, hogy a sztómával hosszabb ideje együtt élő embereknek nagyobb terük volt alkalmazkodni a nehéz élethelyzethez. Az a sztómás, aki jobban alkalmazkodik a megváltozott helyzethez, az életminőségével kapcsolatban magasabb szubjektív elégedettségről vallhatna. A kereszttáblás elemzés és a függetlenségvizsgálat szerint a két változó kapcsolatát lehet kimutatni $(\chi 2(15, \mathrm{~N}=178)=27,48254, \mathrm{p}=$ 0,02504). Az életminőség és a sztóma időtartama közti függőséget mérő kontingencia-együttható értéke 0,37 (1 a teljes függőséget, 0 a függetlenséget mutatja; a vizsgálati eredmény statisztikailag szignifikáns). 
Az összes válaszadóból az olyan sztómás, akinek tíz éven belüli időszakban van kivezetése $(55,26 \%)$ elmondta, hogy a jelenlegi helyzetet már megszokta. A tíz évnél régebbi sztómások közül a 48,68\% jelentette ki, hogy szintén megszokta a nehéz élethelyzetet. A sztómások 47,62\%-a, akiknek öt éven belüli időszakban van sztómájuk, és a kérdőívben elárulta, hogy szintén megszokták az életet a kivezetéssel. A betegek 45,45\%-nak, akiknek legrövidebb ideje van kivezetése, a legfontosabbnak azt tartotta, hogy a sztóma megmentette az életüket. A sztómások többsége szerint megszokták a nehéz élethelyzetüket és fontos számukra, hogy a sztóma megmentette az életüket. Ezek a válaszok jellemzőek a sztómások mind a négy csoportjára, melyet a sztómások besorolására hoztunk létre a kivezetés időtartama alapján. Ezzel ellentétben azokat a válaszokat, hogy „ennél rosszabb nem is történhetett volna velem” vagy „elégedetlen vagyok”, a sztómások alacsony százaléka adta. Az egy éven belüli sztómások 4,55\%-nak válaszaiból kitűnik, hogy szerintük semmi rosszabb nem történhetett volna velük. Nagy elégedetlenséget és korlátozottságot csak a sztómások 2,63\%-a jelölte meg a tíz éven belüli időtartamból és 4,55\%-a a sztóma kialakításának első évében. A megállapított adatok alapján igazolni látszódik a feltételezésünk, hogy a hosszabb ideje sztómával élő betegek jobban alkalmazkodnak a nehéz élethelyzethez és éppen ennek a csoportnak a 70\%-a nagyon elégedett az életminőségével. Egyúttal ennek a csoportnak a válaszaiból kitünik, hogy az adott helyzethez alkalmazkodtak, méghozzá szinte a 45 százalékuk.

A sztóma időtartama

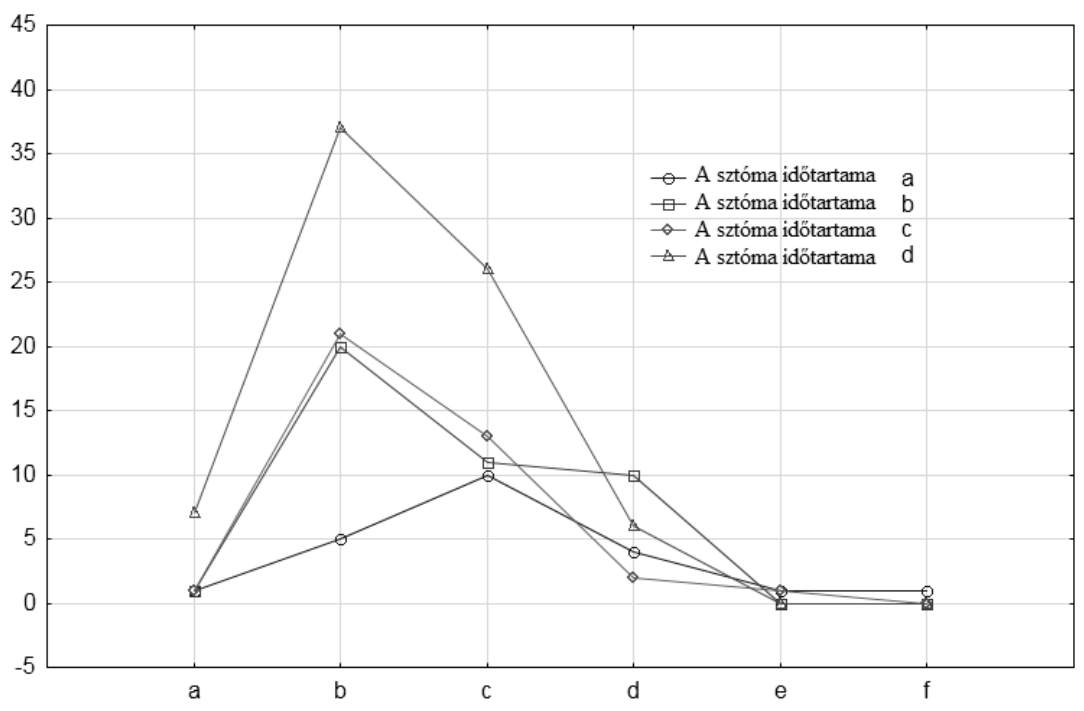

5. ábra. A sztóma időtartama és az életminőség összefüggése. 
Az eredményeket az 5. ábrán mutatjuk be. Az x tengelyen a életminőségre adott válaszok találhatók; az y tengelyen pedig a megfigyelt gyakoriságok, miközben a tétel összes szintjén a sztóma időtartama egy poligonban van feltüntetve.

Ha a görbék másolják egymás - egyforma lefolyásuk van, akkor a válaszok függetlenek. Ellenkezőleg, ha bizonyos függőség állna fenn, akkor a görbék nem másolnák egymást - különbözőképpen futnának. Ebben az esetben a görbék nem másolták egymást, különböző lefolyásuk van - ami a számítási eredményeket szemlélteti.

Az 1-es számú hipotézis tehát bizonyítható: Azok a sztómások, akiknek régebben van sztómájuk, magasabb szubjektív elégedettségről vallottak életminőségükkel kapcsolatban a kivezetés után, mint azok a betegek, akiknek rövidebb ideje van kivezetésük.

\section{2. kutatói kérdés: Milyen mértékben volt hatással az adott személy a sztóma kivezetése előtti élete a kivezetés utáni életminőségre?}

A kiinduló sejtés szerint azok a válaszadók, akik szubjektív elégedettséget tüntettek fel az életminőségük terén a sztóma előtti életükből, ugyanolyan szubjektív elégedettséget tüntetnek fel az életminőségükről a kivezetés elvégzése után.

A vizsgálat során összehasonlítottuk a szubjektív elégedettséget az életminőség értékelésnél a sztóma kialakítása előtt (4. ábra) és a sztóma kialakítása után (3. ábra). Az életminőséggel való elégedettséget, illetve elégedetlenséget a sztómások számskálán fejezték ki, melyen 7 érték volt. A 0 a nagyon rosszat jelentette, a 6 pedig a nagyon jót.

Feltételeztük, hogy a válaszadó, aki az életminőségével a sztóma kialakítása előtt meglehetősen elégedett volt, az meglehetősen elégedett az életminőségével a sztóma kialakítása után is. Ellenkezőleg, a sztóma kialakítása előtt az életminőségével elégedetlen beteg hozzávetőleg hasonló értékeket jelölt be a számskálán a sztóma kialakítása utáni életminőségéről. A feltüntetett eredményekből megállapíthatjuk, hogy a sztóma kialakítása nincs jelentős hatással az ember életminőségének változására. A két megítélés szorosságát mérő Kendall-féle korrelációs együttható értéke az elemzésben 0,21 értéket mutatott $(\mathrm{N}=178 ; \mathrm{Z}=$ 4,23; $\mathrm{p}=0,000023$ ) Ezek alapján megállapítást nyert az alacsony szintü függöség - a korrelációs együtthatás statisztikailag szignifikáns volt.

A válaszadók nagyobb többsége (több mint $85 \%$ ) jó és nagyon jó életminőségről számolt be a sztóma előtti, de a kivezetés utáni életminőségéről is. Elégedetlenséget az életminőségükkel kapcsolatban a számskálán csak ritkán tüntettek fel, méghozzá 11\%, a 3-as számtól lefelé a sztóma után, és hozzávetőleg 15\% a 
sztóma elvégzése előtt. A 6. ábra a függőségeket ábrázolja. Látható, hogy a két tétel értékei egyenletesen oszlanak el a rendszerben.

A második kutatói feltételezés szintén bizonyítást nyert: A válaszadók, akik szubjektív elégedettséget tüntettek fel az életminőségük terén a sztóma előtti életükből, ugyanolyan szubjektív elégedettséget tüntetnek fel az életminőségükről a kivezetés elvégzése után.
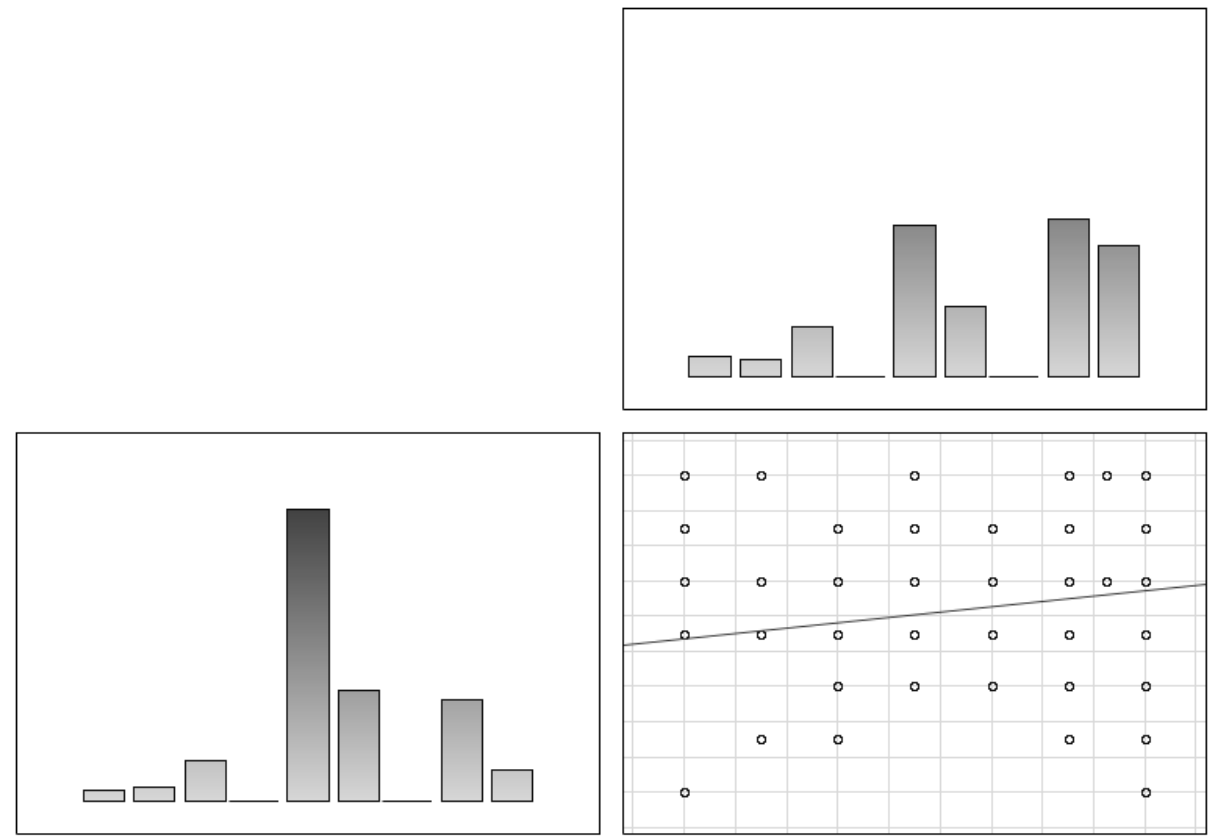

6. ábra. Az életminőségi mutatók eloszlásai a sztómás kivezetés előtt és után.

\section{Megbeszélés}

A vizsgálatok során feltételeztük, hogy a hosszabb ideje sztómával élők nagyobb szubjektív elégedettségről tesznek tanulságot az életminőségüket illetően, mint a rövidebb ideje sztómával élők. Ennek oka lehet, hogy a hosszabb ideje sztómával élőnek nagyobb tere van a nehéz élethelyzethez való alkalmazkodásra. Az első hipotézis igazolására a kutatott célcsoport függőségét vizsgáltuk a sztóma kialakításának ideje és a kérdőív „Hogyan értékelné életminőségét a sztóma kialakítása után?” tétele szerint. A sztómások többsége elmondta, hogy a 
nehéz élethelyzethez már hozzászoktak, és számukra az a fontos, hogy a sztóma kialakítása megmentette az életüket. Ezt a választ a sztómások összes csoportja megjelölte, akiket az adott kategóriában megfigyeltünk. Csak a sztómások alacsony aránya - kevesebb, mint 5 százaléka az egy éven belüli sztómások közül mondta az, hogy ennél rosszabb már nem is történhetett volna vele. Azok a sztómások, akiknek régebben van sztómájuk, magasabb szubjektív elégedettségröl vallottak életminőségükkel kapcsolatban a kivezetés után, mint azok a betegek, akiknek rövidebb ideje van kivezetésük.

Összehasonlítottuk a szubjektív elégedettséget az életminőséggel a sztóma kialakítása előtt és a sztóma kialakítása után. Feltételeztük, hogy az a válaszadó, aki elégedett volt életminőségével a sztóma kialakítása előtt, az a sztóma kialakítása utáni életminőségéről is hasonlóan nyilatkozott. A válaszadók, akik magasabb szubjektív elégedettséget tüntettek fel az életminőségük terén a sztóma elötti életükről, ugyanolyan szubjektív elégedettséget tüntettek fel az életminőségükről a kivezetés elvégzése után. Ez véleményünk szerint a beavatkozás eredményének pozitív hatását tükrözi. Így az eredményekből megállapíthatjuk, hogy a sztóma kialakítása nem csökkenti jelentős mértékben az egyén életminöségét. A sztómások minimális száma nyilatkozott úgy, hogy a sztóma az életminőségükkel való elégedetlenségük oka.

\section{Összegzés}

Az életminőségben jelentősen visszatükröződik a személyes jóllét (well-being), az önmagunkról való gondoskodás képessége (önellátás), a mobilitás szintje és a saját életünket irányítani tudás szintje. Néhány újabb kutatás ebben a tekintetben a személyes jóllétet különböző körülmények között, mint az életminőség standardját határozza meg (Van Der Steen és mtsai., 2001, In Kebza, 2005).

A. Hunt (2003) tanulmányában a személyes jóllét és az élettel való elégedettség fő előnyeit a fizikai állóképességben foglalta össze. Az állóképesség kedvezően hat a metabolizmusra és az optimális testsúly megtartására. Ezen kívül hatással van a rendellenességek és a betegségek kialakulására, valamint részlegesen a megelőzésére is. Az idősebbek esetében főleg a teljes függetlenség és önállóság kerül előtérbe. Igazolható, hogy a magasabb szintű fizikai állóképességgel megnő az életminőség szintje is (In Kebza 2005).

Schmuck és Scheldon (2001) hangsúlyozzák a különbséget a funkcionális jólét és a jóllét, mint állapot között. A személyes jólétet úgy értelmezik, mint az elégedettség, a boldogság, a pozitív hangulat és a szubjektív, magas szintü egészség kombinációját. Könyvükben összegyüjtötték a személyes jólléttel kap- 
csolatban a percepció és az életcélok szemszögéből készült tanulmányokat. Az életcélokat (life goals), mint speciális motivációs célokat határozzák meg, melyekkel az emberek az életüket irányítják egy bizonyos idő alatt. Az említett szerzők két eredményt emelnek ki, melyek a célok megitélésére és a well-beingre vonatkoznak. Az első eredmény szerint a hosszú távú célok szorosabban kapcsolódnak a személyes jólléthez, mint a rövidtávú célok. A második eredménynél a személyes jóllét esetében az önmagunkkal való összhang (selfconcordance) jelentőségét hangsúlyozzák, amely kifejezi az ember és az implicit emberi érdekek és értékek összhangját (In Kebza 2005).

A sztómával való élet nagy változást jelent a sztómás beteg személyes életében, de a családtagjai és a hozzátartozói életében is. Az új valósághoz való alkalmazkodás és a változás tényének elfogadása néha nagyon hosszú ideig is eltarthat. A sztómás kivezetés több esetben megmentheti a páciens életét vagy jelentősen meghosszabbíthatja, illetve minőségesebbé teheti azt. Minden sztómásnak tudnia kellene, hogy a kivezetéssel meg lehet tanulni élni (Linhartová, 2012).

\section{Irodalomjegyzék}

1. HALEČKA, T. 2001. Kvalita života ako pojem a problém sociálnej politiky a sociálnej práce. In HROZENSKÁ, M. és mtsai. 2008. Sociálna práca so staršími l'ud'mi. Osveta : Martin, 2008. 181. s. ISBN 978-80-8063-283-3. (http://www.slovilco.sk/definicia/ 2016.04.28).

2. HUNT, A. Musculoskeletar fitness: the kyestone in overall well-being and injury prevention. In KEBZA, V. 2005. Psychosociální determinanty zdraví. Praha : Academia, 2005. 263 s. ISBN 80-200-1307-5.

3. KOVÁČ, D. 2007. Psychológiou k metanoi. Bratislava : Veda, 2007. 484 s. ISBN 978-80-224-0965-0.

4. LINHARTOVÁ, J. 2012. Usnadnit život pacientům se stomií. In Diagnóza v ošetřovatelství. ISSN 1801-1349, 2012, roč. VIII., č. 1, s. 10-11.

5. MATOUŠEK, O. - KOLÁČKOVÁ, J. - KODYMOVÁ, P. és mtsai. 2005. Sociální práce v praxi. Praha : Portál, 2005. 352 s. ISBN 80-7367-002-X.

6. MATOUŠEK, O. és mtsai. 2007. Sociální služby. Praha : Portál, 2007. 184 s. ISBN 978-80-7367-310-9.

7. SCHMUCK, P. - SCHELDON, K. M. 2001. Life goals and wellbeing.Towards a positive psychology of human striving. In KEBZA, V. 2005. Psychosociální determinanty zdraví. Praha : Academia, 2005. 263 s. ISBN 80-200-1307-5. 
8. SURYNEK, A. - NOVÝ, I. 2006. Sociologie pro ekonomy a manažery. In HEŘMANOVÁ, E. 2012. Koncepty, teorie a měření kvality života. Praha : Slon, 2012. 239 s. ISBN 978-80-7419-106-0.

9. ŠALGOVIČOVÁ, J. 2007. Dôležité aspekty kvality života v podmnienkach globalizovanej ekonomiky. In HEŘMANOVÁ, E. 2012. Koncepty, teorie a měření kvality života. Praha : Slon, 2012. 239 s. ISBN 978-80-7419-106-0.

10. VAN DER STEEN, J. T. és mtsai. 2001. Kwaliteit van leven en dementie II. In KEBZA, V. 2005. Psychosociální determinanty zdraví. Praha : Academia, 2005. 263 s. ISBN 80-200-1307-5.

A szerző

\section{Stela Gilanová}

A pozsonyi Szent Erzsébet Egészségügyi és Szociális Munka Főiskola doktorandusza

stelag@centrum.sk 
